Article

\title{
Biogas Potential for Improved Sustainability in Guangzhou, China-A Study Focusing on Food Waste on Xiaoguwei Island
}

\author{
Roozbeh Feiz ${ }^{1}\left(\right.$, Jonas Ammenberg ${ }^{1}{ }^{\circledR}$, Annika Björn ${ }^{2}$, Yufang Guo ${ }^{3, *}$, Magnus Karlsson ${ }^{1}$, \\ Yonghui Liu ${ }^{3}$, Yuxian Liu ${ }^{4}$, Laura Shizue Moriga Masuda ${ }^{5}$, Alex Enrich-Prast ${ }^{2}$, \\ Harald Rohracher ${ }^{6}{ }^{D}$, Kristina Trygg ${ }^{6}{ }^{\circledR}$, Sepehr Shakeri Yekta ${ }^{2}$ and Fagen Zhang ${ }^{3}$ \\ 1 Department of Management and Engineering, Division for Environmental Technology and Management, \\ Linköping University, Linköping 58183, Sweden; roozbeh.feiz@liu.se (R.F.); jonas.ammenberg@liu.se (J.A.); \\ magnus.karlsson@liu.se (M.K.) \\ 2 Department of Thematic Studies, Environmental Change, Linköping University, Linköping 58183, Sweden; \\ annika.bjorn@liu.se (A.B.); alex.enrich.prast@liu.se (A.E.-P.); sepehr.shakeri.yekta@liu.se (S.S.Y.) \\ 3 School of Environmental Science and Engineering, Guangzhou University, Guangzhou 510006, China; \\ liuyh@263.net (Y.L.); dustinzh@263.net (F.Z.) \\ 4 Linköping University-Guangzhou University Research Center on Urban Sustainable Development, \\ Guangzhou University, Guangzhou 510006, China; liuyuxian@gzhu.edu.cn \\ 5 Institute of Biology, Federal University of Rio de Janeiro, Rio de Janeiro, RJ 21941-902, Brazil; \\ shizuemm@yahoo.com.br \\ 6 Department of Thematic Studies, Technology and Social Change, Linköping University, Linköping 58183, \\ Sweden; harald.rohracher@liu.se (H.R.); kristina.trygg@liu.se (K.T.) \\ * Correspondence: guoyf913@126.com
}

Received: 2 February 2019; Accepted: 7 March 2019; Published: 14 March 2019

\begin{abstract}
As a result of rapid development in China and the growth of megacities, large amounts of organic wastes are generated within relatively small areas. Part of these wastes can be used to produce biogas, not only to reduce waste-related problems, but also to provide renewable energy, recycle nutrients, and lower greenhouse gases and air polluting emissions. This article is focused on the conditions for biogas solutions in Guangzhou. It is based on a transdisciplinary project that integrates several approaches, for example, literature studies and lab analysis of food waste to estimate the food waste potential, interviews to learn about the socio-technical context and conditions, and life-cycle assessment to investigate the performance of different waste management scenarios involving biogas production. Xiaoguwei Island, with a population of about 250,000 people, was chosen as the area of study. The results show that there are significant food waste potentials on the island, and that all studied scenarios could contribute to a net reduction of greenhouse gas emissions. Several socio-technical barriers were identified, but it is expected that the forthcoming regulatory changes help to overcome some of them.
\end{abstract}

Keywords: biogas; food waste; system study; biomethane potential; socio-technical study; megacities; China; Guangzhou city; Xiaoguwei Island

\section{Introduction}

\subsection{Background}

Since the reforms in the late 1970s, there has been a rapid economic development in China, involving industrialization and urbanization [1]. In 1980, about $19 \%$ of the population lived in urban areas, while the corresponding figure was 50\% in 2010 [2]. This trend is expected to 
continue, with increasing shares of the population living in cities [3]. The urbanization has created and expanded several megacities such as Beijing, Guangzhou and Shanghai [4], among others. These, and other large cities in China and elsewhere, commonly face a wide range of environmental challenges, e.g., [5], related to air pollution [6-8], water pollution and management [9,10], noise [11,12], and waste management $[13,14]$. Cities are also to a large extent dependent on supplies of food, energy (energy security) and other essential products from the surrounding world.

During the last decades, there have been policy changes in China that signal a revised view of the desired development [15]. Fewsmith [16] indicates that the previous, relatively narrow focus on economic growth has been balanced by a broadened perspective where environmental issues, including management of natural resources, have received a higher priority. There is a wide range of strategies to tackle the mentioned environmental challenges. As the extensive use of fossil fuels, mainly in the energy and transportation sector, contributes to many of the mentioned problems, many regions, nations and cities are replacing fossil fuels with renewable alternatives such as biogas [17-22]. If the biofuels are waste-based, it is possible to simultaneously address waste-related problems and create fuels or electricity and other essential products and services.

This article focuses on biogas, which is produced via anaerobic digestion of organic materials. In comparison with other biofuels, it is more flexible, because it can be produced from hydrocarbons, proteins and fats [23], including wet and secondary materials, e.g., [24]. For example, biogas is commonly produced from food waste (FW), sewage sludge and manure, but how biogas is produced and used varies between countries, with different feedstock, production and use [25]. In addition to biogas, the anaerobic digestion process delivers a second output-digestate. As a large share of the nutrient content of the feedstock ends up in the digestate, it can be used as a biofertilizer contributing to improved nutrient management $[26,27]$.

According to $\mathrm{Gu}$ et al. [28], biogas has been produced for almost a century in China, with a strong expansion in 2000-2010. The production is to a large extent (very) small-scale, as most of the gas is produced within rural households and the agricultural sector [28-30]. However, while the household production may have reached its peak, the agricultural biogas production has lately increased. Biogas production also seems to be shifted towards larger-scale and centralized plants with increasing numbers of industry-based projects [28], cf. [30-33]. There are also examples of larger plants established to produce biogas from food waste. Biogas solutions appear to fit well with several prioritized environmental policy areas [28], and there is a range of Chinese policy instruments that support renewable energy and fuels, and specifically biogas $[15,16,34]$ - Renewable fuels in general, and biogas in particular, can also fit well into strategies regarding a biobased and circular economy, for which there are central objectives and a strong commitment in China [35]. Biogas from food waste is also in line with a series of recent policies proposed to better manage and recycle food waste, and to utilize the great potential of recycling the organic wastes in large Chinese cities; for example, see [36-38], cf. [39] (p. 9). However, despite the policy support, Gu et al. [28] conclude that after a long period with a relatively steady increase in the total biogas production, there was a decrease around 2015. The rural production went down faster than the agricultural production grew and was not compensated for by the slowly increasing industrial production. Several different factors explain this. There are reports on rudimentary technical levels, technical problems and a low level of competency as hindering, leading to inefficient production and digesters taken out of production $[28,29,32]$. There may also be a need for revised policy [40], shifting focus from production plants to the generation and use of biogas and biofertilizers. An important part of the decrease can also be linked to the mentioned urbanization, as the decline in rural population and small livestock breeding is connected to the reduction of small-scale rural biogas production [28]. Su et al. [41] mention the national objective to produce 440 billion $\mathrm{m}^{3}$ of biogas in the year 2020, which could correspond to almost $3000 \mathrm{TWh} /$ year cf. [34] (The estimation depends on the energy content of the gas; and the unit is also a bit uncertain, but it is assumed to regard $\mathrm{Nm}^{3}$. Assuming the methane content of biogas to be $63 \%$, and an energy density of $36.4 \mathrm{MJ} / \mathrm{m}^{3}$ 
methane, the total becomes 2803 TWh). But after a thorough analysis, Gu et al. [28] foresee an ongoing decrease in the coming decade, indicating that national objective will not be reached.

The described development with changing lifestyles and large populations within megacities means that huge amounts of waste are generated within relatively small areas [29], cf. [42]. Several types of waste streams are growing [43] cf. [44,45]. For example, the yearly generated amounts of municipal solid waste (MSW) have been estimated to have grown from about 31 million tons in 1980 to 180 million tons in 2014 [46], corresponding to an increase by a factor of six. However, these kinds of estimations seem to vary significantly between different sources [43], cf. [44,45]. Dou [45] estimates that more than $50 \%$ of the MSW in China consists of food waste, but there are also other organic contents such as garden waste. $\mathrm{Gu}$ et al. [46] provide a review with even higher shares of food waste (exceeding $60 \%$ ). Commonly, MSW is not classified and sorted at the source [29]. The dominant treatment methods in China are landfilling or incineration, where $82 \%$ was landfilled and $15 \%$ incinerated in 2008 [29,46,47]. Central landfills require valuable land and cause different types of environmental and health-related effects, e.g., [48]. Due to the high moisture content of the mixed waste in China, incineration of untreated MSW often has a relatively low efficiency [39,49], also see [50,51]. Some of the food waste is used as animal feed, and recently, composting has become popular in some areas [45].

In conclusion, there seems to be great potential in China, not least in the megacities, to produce biogas from food waste and thereby provide renewable energy, recycle nutrients, significantly lower GHG and air polluting emissions, and reduce essential waste-related problems.

\subsection{Research Context and Aim}

There are relatively few peer-reviewed studies that investigate the potential and performance of producing biogas from food waste in Chinese cities from a life-cycle perspective. A search in the Web of Science using the keywords biogas, life cycle, China and waste led to 45 entries (mainly published between 2015 and 2018), out of which only 17 contained food waste or kitchen waste as part of their topic. In a closer look, it became clear that only a few of these papers focused on food waste and adopted a life-cycle approach in their analysis. These papers were constructed differently, were based on different sets of assumptions, and often had a narrow technological focus.

The advantages of treating food waste using anaerobic digestion have been frequently demonstrated-and in a few cases questioned-in different contexts (for example, see: [52-56]). The important issue, however, is to investigate how biogas production from food waste can fit, in relation to other treatment options and considering the larger socio-technical picture, in a certain municipal context. Therefore, while it is beneficial to focus on technical choices and how they compare against each other, it is also important to consider how diverting food waste from existing paths, toward biogas production, affects the environmental impact of the waste treatment and the systems that are related to it.

The overall purpose of this research was to contribute to increased knowledge about the potential and conditions for biogas and biofertilizer production in Guangzhou, and study how and to what extent biogas solutions can:

- improve waste management,

- provide renewable energy and biofertilizers, and

- contribute to the substitution of fossil fuels and mineral fertilizers, and

- lead to reduced emissions of greenhouse gases and better nutrient recycling (and potentially other types of impacts) from a life-cycle perspective.

The city of Guangzhou has a population of about 12.7 million inhabitants within the city's administrative area including districts and counties, of which 11.1 million people live in the city districts [57]. However, there is no biogas production at the moment. 


\subsection{The Studied Case: Xiaoguwei Island and the Guangzhou Higher Education Mega Center}

This article is focused on food waste in the area of Xiaoguwei Island and its food waste as potential feedstock for biogas and biofertilizer production. Xiaoguwei Island was chosen as it is a well-defined area with a reasonable size to map waste flows. This island is to a large extent dedicated to be used by universities - the Guangzhou Higher Education Mega Center (HEMC) is situated there, with ten universities, including Guangzhou University. Thus, the researchers from Guanghzou had good knowledge about this part of the city.

Xiaoguwei Island is approximately $18 \mathrm{~km}^{2}$ and is planned to accommodate up to 400,000 people. The current population is approximately 250,000 people (Figure 1 ).

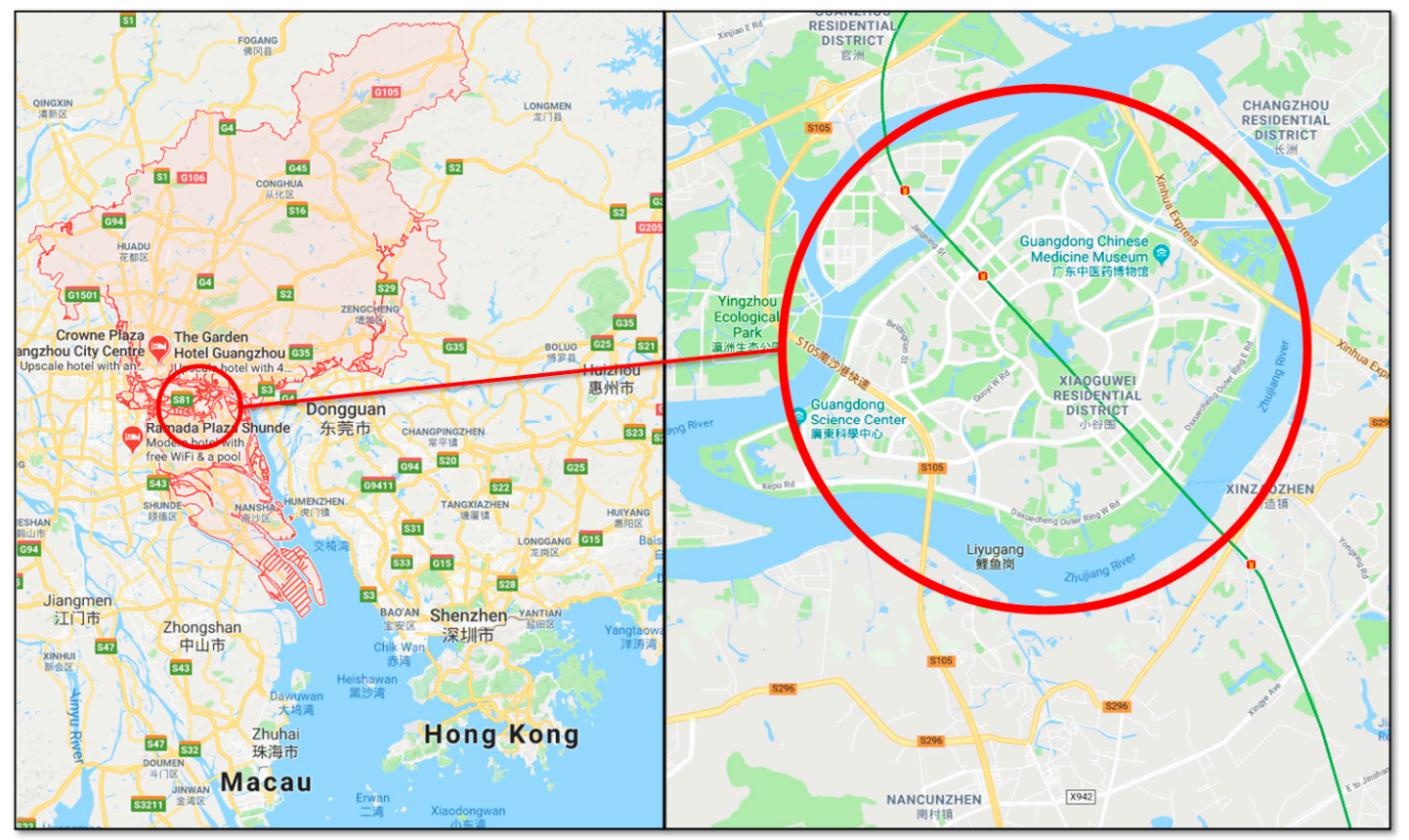

Figure 1. Location of Xiaoguwei Island in relation to Guangzhou [58].

\section{Materials and Methods}

Several methods of different character were used to reach the aim. Table 1 provides an overview of these methods (and activities) and shows to what extent they have contributed to different questions: the rows designate various areas and research questions, while the columns show various methods or activities that were pursued. The number of stars shows how relevant each method/activity is to each area/question. 
Table 1. Overview showing research methods and activities and to what extent they have contributed to answering the questions. The stars designate the relevance for each question $\left({ }^{* * *}\right.$ high, ${ }^{* *}$ medium, ${ }^{*}$ low $)$.

\begin{tabular}{|c|c|c|c|c|c|c|}
\hline $\begin{array}{c}\text { Methods/Activities } \rightarrow \\
\quad \text { Areas/Questions } \downarrow\end{array}$ & Workshops & $\begin{array}{l}\text { Literature and } \\
\text { Document Studies }\end{array}$ & Interviews & $\begin{array}{l}\text { Lab Analysis of } \\
\text { Food Waste }\end{array}$ & $\begin{array}{l}\text { Scenario } \\
\text { Formulation }\end{array}$ & $\begin{array}{l}\text { System Modeling } \\
\text { and Analysis }\end{array}$ \\
\hline Food waste management: - types, sources and amounts? & ** & $* *$ & $* * *$ & & & \\
\hline Characteristics of food waste: - composition, methane potential? & * & $* * *$ & * & $* * *$ & & \\
\hline $\begin{array}{c}\text { Biogas and nutrient recycling potential: - amount of biogas, } \\
\text { biofertilizer? }\end{array}$ & * & ** & $* *$ & & ** & $* * *$ \\
\hline How to use the biogas and digestate? & * & * & $* *$ & * & $* * *$ & \\
\hline Environmental impacts: - climate impact & & & & & $* *$ & $* * *$ \\
\hline $\begin{array}{c}\text { Conditions for implementation of biogas solutions from a } \\
\text { socio-technical perspective? }\end{array}$ & $* *$ & * & $* * *$ & & & \\
\hline
\end{tabular}


The methods/activities in Table 1 are described in the following sections.

\subsection{Workshops}

This study was carried out as a cooperation of researchers from Linköping University (LiU) and Guangzhou University (GZU). Workshops and other relevant activities have been important for the setting up of the study including discussing research interests, developing project plans, specifying the project organization and activities, exchanging and discussing relevant information, and so on. The first workshop was held in Guangzhou (December 2015) and involved researchers and city representatives from Guangzhou and Linköping. In addition to lectures on sustainable urban development, the researchers presented their work and areas of interest, and potential areas of co-operation were discussed. The guests from Sweden got the chance to visit parts of Guangzhou, including a study visit to a waste incineration plant. In December 2016, a project proposal regarding biogas had been developed and granted, which was discussed at another workshop in Guangzhou. This workshop focused on the organization (roles, capabilities, etc.) and specification of the project plan, but also a study visit to a plant using aerobic treatment of food waste. Relevant issues regarding Xiaoguwei Island, waste management, and socio-technical systems were discussed to some extent. In April 2016 a team of researchers from LiU visited Guangzhou, with the main purpose to conduct interviews (see Section 2.3 Interviews), but there were also meetings and other activities to increase the knowledge about waste management, biogas production, etc. Finally, in June 2016 a few researchers from GZU visited LiU. They were educated on essential laboratory facilities and regarding how to conduct substrate (feedstock) characterization. Further on, the project was discussed, including results, data on food waste, and other relevant issues.

\subsection{Literature and Document Studies}

Literature studies have been conducted for several reasons, for example, to learn about biogas production in China, the policy context and other relevant socio-technical aspects. But from a methodological perspective, it should be mentioned that scientific and grey literature have been used to get information about flows of food waste-amounts and how this type of waste is managed, and to estimate the food waste characteristics (e.g., the biomethane potential), as a complement to the laboratory studies that have been carried out. Documents, such as records on canteen food waste flows, have provided more specific information.

\subsection{Interviews}

Semi-structured interviews were carried out to get applicable information about relevant social, economic and institutional conditions. This provided information about the socio-technical context for potential biogas solutions in Guangzhou, which was used to define scenarios for analysis. Since there was no biogas production or use in Guangzhou, the interview study focused on actors involved in -influencing or being influenced by-the food waste system on Xiaoguwei Island. The selection of actors was partially decided based on discussions during the workshops, but also due to information from the respondents that mentioned other actors of relevance. These interviews were mainly focused on the understanding and knowledge regarding the food waste system in Guangzhou in general and the studied area in particular. As support, an interview guide consisting of five parts was developed and used:

1. The role of the organization, the respondents' background and roles

2. The existing systems for food waste management and their historical development

3. Involved actors

4. Regulations of relevance

5. Future development 
This guide was adapted for each interview, considering the role of the selected organizations and respondents. In total, five actors were selected for interviews focusing on food waste, which are presented in Table 2.

Table 2. Short description of the five actors who were interviewed focusing on food waste management.

\begin{tabular}{llll}
\hline Organization & Respondents & Short Description & $\begin{array}{l}\text { Working Experience within } \\
\text { This Organization }\end{array}$ \\
\hline Xiaoguwei street office & Office director & $\begin{array}{l}\text { Sub-district office on } \\
\text { Xiaoguwei island, in } \\
\text { charge of environmental } \\
\text { hygiene management }\end{array}$ & 8 years \\
\hline $\begin{array}{l}\text { Guangzhou Municipal } \\
\text { Administration }\end{array}$ & $\begin{array}{l}\text { Director of Guangzhou } \\
\text { city management } \\
\text { technology research } \\
\text { center }\end{array}$ & $\begin{array}{l}\text { Engaged in the } \\
\text { construction and } \\
\text { improvement of } \\
\text { management systems }\end{array}$ & 10 years \\
\hline $\begin{array}{l}\text { Guangzhou Datianshan } \\
\text { kitchen waste/food } \\
\text { waste plant }\end{array}$ & $\begin{array}{l}\text { Factory Director, } \\
\text { Deputy general } \\
\text { manager }\end{array}$ & $\begin{array}{l}\text { Operating, developing } \\
\text { projects, external public } \\
\text { relation }\end{array}$ & 5 years at Guangdong golden \\
\hline $\begin{array}{l}\text { Classification } \\
\text { Management Office in } \\
\text { Yuexiu District, City } \\
\text { Administration Bureau }\end{array}$ & Office director & $\begin{array}{l}\text { In charge of garbage } \\
\text { classification }\end{array}$ & 12 years \\
\hline $\begin{array}{l}\text { Institute of energy } \\
\text { conversion }\end{array}$ & $\begin{array}{l}\text { Associate researcher, } \\
\text { Master Advisor }\end{array}$ & $\begin{array}{l}\text { Biomass biochemical } \\
\text { conversion, responsible } \\
\text { for research work (have } \\
\text { studied biogas potential) }\end{array}$ & 12 years \\
\hline
\end{tabular}

To get information from a company producing biogas from food waste in China, two employees from the Haikou Biogas Plant, located in Haikou city in the Hainan province, were interviewed: one working as an assistant general manager, and the other as Deputy Director of Development and Head of R\&D Centre. Both had worked at the plant for five years.

\subsection{Laboratory Analysis of Food Waste}

In addition to the literature studies on food waste, the project involved laboratory analysis to get more specific information about the characteristics of some selected food waste streams in the campus area (i.e., on Xiaoguwei Island). Bio-methane potential (BMP) tests were conducted, which are important to determine the biodegradability and decomposition rate of organic materials and estimate how much methane can be produced by anaerobic digestion with a certain amount of feedstock [59].

Food waste was collected in four different restaurants and canteens in the Guangzhou University area, during two days in April 2017, at different times of the day (lunch or dinner). This waste was preserved in plastic bottles at $-20^{\circ} \mathrm{C}$ in order to be transported to Sweden, and before starting the analysis it was thawed and mixed with a kitchen blender to ensure uniform experimental materials in all the bottles. The inoculum (source of anaerobic microorganisms) was obtained from the Åby biogas plant in Linköping, Sweden, where food waste is the main feedstock (substrate) for biogas and biofertilizer production. The inoculum was pre-incubated at $37^{\circ} \mathrm{C}$ for two days before starting the BMP tests, to decrease the gas production, and to obtain better results of biodegradability of the organic substrate [59]. The inoculum used contained $5 \%$ of total solids (TS) and $71 \%$ of volatile solids (VS; based on TS), and a pH of 7.98.

The bio-methane potential of the food waste was evaluated in batch bottles of $320 \mathrm{~mL}$ with $100 \mathrm{~mL}$ of working volume. The test was performed with the food waste (around $2.5 \mathrm{~g} \mathrm{VS} / \mathrm{L}$ ), $20 \mathrm{~mL}$ of inoculum, nutrient solution and salts $\left(\mathrm{NH}_{4} \mathrm{Cl}, 0.3 \mathrm{~g} \mathrm{~L}^{-1} ; \mathrm{NaCl}, 0.3 \mathrm{~g} \mathrm{~L}^{-1} ; \mathrm{CaCl}_{2} .2 \mathrm{H}_{2} \mathrm{O}, 0.1 \mathrm{~g} \mathrm{~L}^{-1}\right.$; and $\mathrm{MgCl}_{2} \cdot 6 \mathrm{H}_{2} \mathrm{O}, 0.1 \mathrm{~g} \mathrm{~L}^{-1}$ ), and the experimental bottles were flushed with $\mathrm{N}_{2}$ and sealed with rubber stoppers and aluminum screw caps according to the method described by Ekstrand et al. [60]. One treatment was performed just with inoculum to discount the values of methane production, 
and one treatment with cellulose (Whatman filter paper No. 3) to ensure the proper functioning of the community. Each treatment was performed in triplicate and incubated at $37^{\circ} \mathrm{C}$ for 63 days.

The $\mathrm{pH}$ was analyzed with a PHM93 pH-meter (Radiometer, Copenhagen, 166 Denmark). For determining TS and VS, the organic material was dried at $105{ }^{\circ} \mathrm{C}$ overnight and then put in the furnace for two hours at $550^{\circ} \mathrm{C}$ [61] according to the standard method [62]. Total gas production was calculated by the pressure measurements with a Testo 312-3 Precision manometer (Testo Inc., West Chester, PA, USA). For bio-methane content, the samples were analyzed by gas chromatography (HP 5880A Series, Hewlett Packard, Palo Alto, CA, USA) according to Karlsson et al. [63]. All gas volumes were normalized to $1 \mathrm{~atm}$. pressure and $273 \mathrm{~K}$.

\subsection{Scenario Formulation, System Modeling, and Analysis}

To analyze what role biogas solutions could have in relation to the food waste flows on Xiaoguwei Island, a few scenarios were developed and analyzed. They were based on information about the existing food waste management system, received via the interviews, workshops and literature study. These sources also provided some information of relevance regarding future development, which was combined with more generic knowledge about the production and use of biogas in other parts of the world, in contexts involving food waste in cities.

Figure 2 shows different alternatives regarding how the food waste on Xiaoguwei Island can be managed. It is estimated that presently, about one-third of the waste is sent to the Datianshan plant, where aerobic processes are used to produce biofertilizer/soil conditioners (see Section 4). Slightly less is landfilled, and a similar amount is sent to pig farms as fodder. The circa $10 \%$ remaining is assumed to be incinerated in a power plant (please see Table 3, the first row: "Base"). In addition to the current practices, the figure shows several options involving biogas and biofertilizer production. The raw biogas can be used in different ways with varying consequences:

- upgraded and then used as a transportation fuel substituting diesel;

- upgraded and injected into the gas grid substituting natural gas; and

- for production of electricity, with full, partial, or no heat recovery, with recovered heat used within the biogas plant or in a centralized cooling system.

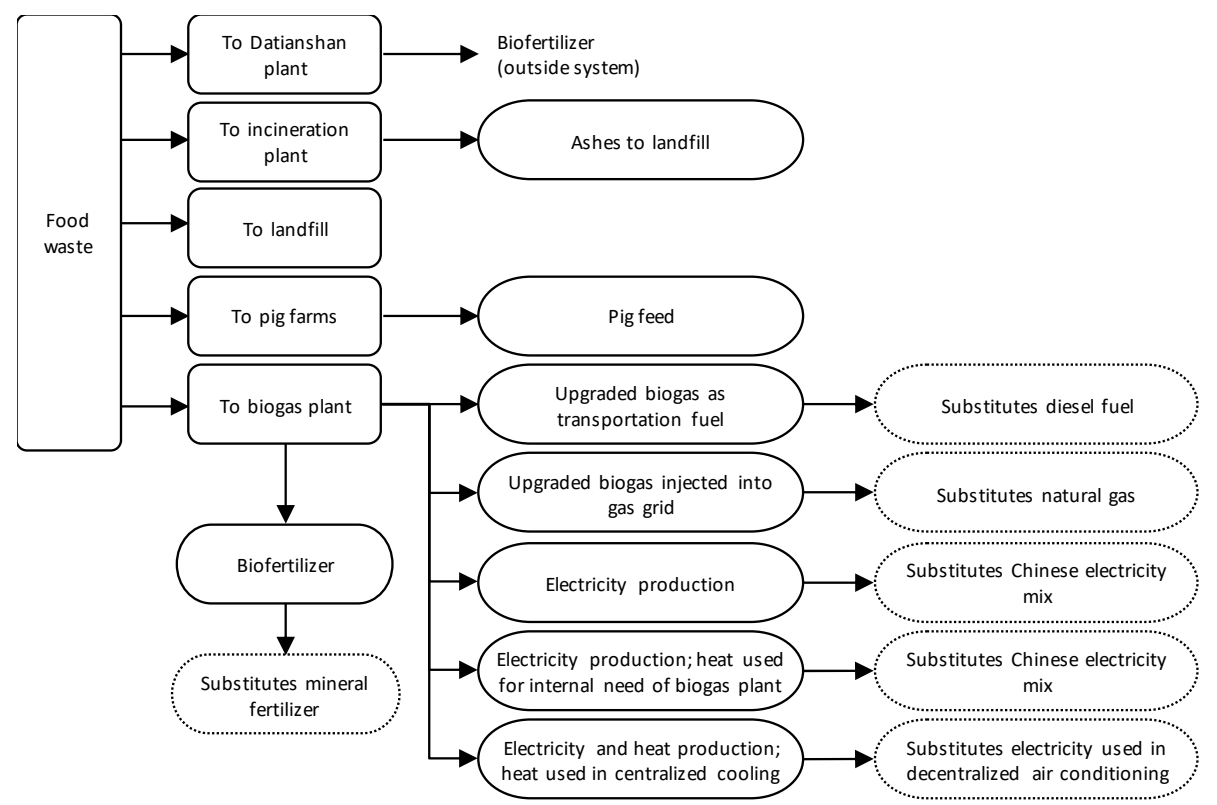

Figure 2. Schematic overview of the existing waste management system on Xiaoguwei Island, and scenarios involving biogas and biofertilizers. 
Table 3. Basic information about the studied scenarios, including codes that are used in the chapter with results. Rows shown in italics (only incineration (ALL IN), only landfilling (ALL LF), only sending the food waste to pig farms (ALL PF), only biogas production with upgrading to fuel (ALL BG), or only biogas production with electricity production (ALL BG EL)) are presented to allow the comparison of different treatment technologies. FW stands for "food waste".

\begin{tabular}{|c|c|c|c|c|c|c|}
\hline Code & Description & $\begin{array}{l}\text { FW To Danshiantan } \\
\text { Plant (\%) }\end{array}$ & $\begin{array}{c}\text { FW To Incineration } \\
(\%)\end{array}$ & $\begin{array}{c}\text { FW To } \\
\text { Landfill (\%) }\end{array}$ & $\begin{array}{l}\text { FW To Pig } \\
\text { Farms (\%) }\end{array}$ & $\begin{array}{l}\text { FW To Biogas } \\
\text { Plant (\%) }\end{array}$ \\
\hline Base & Existing situation, no biogas production & $33.3 \%$ & $10.0 \%$ & $28.3 \%$ & $28.3 \%$ & $0.0 \%$ \\
\hline$A L L I N$ & Assuming all waste goes to incineration & $0 \%$ & $100 \%$ & $0 \%$ & $0 \%$ & $0 \%$ \\
\hline$A L L L F$ & Assuming all waste goes to landfill & $0 \%$ & $0 \%$ & $100 \%$ & $0 \%$ & $0 \%$ \\
\hline$A L L P F$ & Assuming all waste goes to pig farms & $0 \%$ & $0 \%$ & $0 \%$ & $100 \%$ & $0 \%$ \\
\hline$A L L B G$ & Assuming all waste goes to biogas plant & $0 \%$ & $0 \%$ & $0 \%$ & $0 \%$ & $100 \%$ \\
\hline$A L L B G E L$ & Assuming all waste goes to biogas plant & $0 \%$ & $0 \%$ & $0 \%$ & $0 \%$ & $100 \%$ \\
\hline No LF & $\begin{array}{l}\text { No FW to landfill; biogas is upgraded; } \\
\text { raw biogas for internal heat }\end{array}$ & $33.3 \%$ & $10.0 \%$ & $0 \%$ & $28.3 \%$ & $28.3 \%$ \\
\hline No PF & $\begin{array}{l}\text { No FW to pig farms; biogas is upgraded; } \\
\text { raw biogas for internal heat }\end{array}$ & $33.3 \%$ & $10.0 \%$ & $28.3 \%$ & $0 \%$ & $28.3 \%$ \\
\hline No IN & $\begin{array}{l}\text { No FW to incineration; biogas is upgraded; } \\
\text { raw biogas for internal heat }\end{array}$ & $33.3 \%$ & $0 \%$ & $28.3 \%$ & $28.3 \%$ & $10.0 \%$ \\
\hline No LFandPF & $\begin{array}{l}\text { No FW to pig farms and landfill; biogas is upgraded; } \\
\text { raw biogas for internal heat }\end{array}$ & $33.3 \%$ & $10.0 \%$ & $0 \%$ & $0 \%$ & $56.7 \%$ \\
\hline BG max & $\begin{array}{l}\text { No FW to pig farms, landfill, and incineration; biogas is } \\
\text { upgraded; raw biogas for internal heat }\end{array}$ & $33.3 \%$ & $0 \%$ & $0 \%$ & $0 \%$ & $66.7 \%$ \\
\hline BG real & $\begin{array}{l}\text { Realizable allocation; biogas is upgraded; raw biogas } \\
\text { for internal heat }\end{array}$ & $33.3 \%$ & $5.0 \%$ & $14.2 \%$ & $14.2 \%$ & $33.3 \%$ \\
\hline BG grid & $\begin{array}{l}\text { Based on "BG Real"; biogas is upgraded and injected to } \\
\text { gas grid; raw biogas for internal heat }\end{array}$ & $33.3 \%$ & $5.0 \%$ & $14.2 \%$ & $14.2 \%$ & $33.3 \%$ \\
\hline BG El & $\begin{array}{l}\text { Based on "BG Real"; raw biogas used for electricity } \\
\text { production; raw biogas for internal heat }\end{array}$ & $33.3 \%$ & $5.0 \%$ & $14.2 \%$ & $14.2 \%$ & $33.3 \%$ \\
\hline BG CHPi & $\begin{array}{l}\text { Based on "BG Real"; raw biogas used for electricity } \\
\text { production; recovered heat from combined heat and } \\
\text { power plant for internal heat (CHP) }\end{array}$ & $33.3 \%$ & $5.0 \%$ & $14.2 \%$ & $14.2 \%$ & $33.3 \%$ \\
\hline BG CHPC & $\begin{array}{l}\text { Based on "BG Real"; raw biogas used for electricity; } \\
\text { recovered heat from CHP is used for internal heat, and } \\
\text { centralized cooling }\end{array}$ & $33.3 \%$ & $5.0 \%$ & $14.2 \%$ & $14.2 \%$ & $33.3 \%$ \\
\hline
\end{tabular}


Further on, Figure 2 shows the production and use of biofertilizers, which could replace mineral fertilizers. However, regarding biofertilizers, we have accounted for the production, the transportation of biofertilizers to farms and that mineral fertilizers are substituted, but we have not included effects related to storage and spreading.

To simulate the scenarios, a life-cycle assessment (LCA) model was constructed, based on the schematic system illustrated in Figure 2. It was decided to use the functional unit of "treating one ton of food waste". Several more specific scenarios were defined, with different shares of the food waste allocated to the described alternatives-see overview in Table 3. When the amounts of products (produced or consumed), byproducts, activities, or emissions vary between different scenarios, compensating processes have been added to make the outcome of these scenarios comparable. For example, for a scenario where less food waste is diverted to landfill, the emissions from landfilling have been reduced correspondingly; or, where food waste is diverted from pig farms to biogas production, it has been assumed that pig farmers will compensate for the shortage of food waste (as pig fodder) by using commercial pig fodder.

Since all scenarios involve a combination of different waste treatment options, in order to be able to compare different treatment options individually, we also defined five extra scenarios, each reflecting one type of waste treatment. These are only incineration (ALL IN), only landfilling (ALL LF), only sending the food waste to pig farms (ALL PF), only biogas production with upgrading to fuel (ALL BG), or only biogas production with electricity production (ALL BG EL). These scenarios are not assumed to be realistic but are presented to allow the comparison of treatment technologies themselves.

In order to consider the variations and uncertainties in the lab-reported values regarding the dry matter content (solid content or TS) and organic content (volatile solids or VS) of food waste, biogas yield, and the methane content of the biogas (see Tables 4 and 5), these parameters were used as random variables for the Monte Carlo simulation, and the results were collected from the output of this simulation using a $90 \%$ confidence interval. The results, expressed in global warming potential $\left(\mathrm{GWP}_{100}\right)$, were calculated for each scenario and compared against each other. The food waste flows to the Datianshan plant have been assumed to remain constant in all scenarios. Transportation to this plant is included, but the operation of the plant and impacts related to the biofertilizer/soil conditioning products are not included. Several assumptions regarding the life-cycle inventory and corresponding impacts were made-see Table 4.

The annual amounts of food waste on the island were estimated based on the input from the workshops, interviews, and literature and document studies. 
Table 4. Essential assumptions used in the modeling and simulation. TS: total solids, VS: volatile solids.

\begin{tabular}{|c|c|c|c|}
\hline Parameter & Unit & Value & Reference \\
\hline Dry matter content of food waste (FW) & $\%$ & $21.6-29.8$ & \multirow{4}{*}{ This study, see Section 3} \\
\hline Organic content of FW & VS (\% of TS) & $74.2-84.9$ & \\
\hline Biogas yield from anaerobic digestion of FW & $\mathrm{Nm}^{3}$ biogas/ton $\mathrm{FW}$ & $855 \pm 136$ & \\
\hline Methane content of produced biogas & $\%$ vol. & $42.2 \pm 1.8$ & \\
\hline Electricity use, pretreatment (slurry production) & $\mathrm{MJ} /$ ton FW & 79.2 & {$[64]$} \\
\hline Electricity use in biogas plant (excluding upgrading) & $\mathrm{MJ} /$ ton FW & 122.4 & {$[64]$} \\
\hline Heat use in biogas plant (excluding upgrading) & MJ/ton FW & 334.8 & {$[64]$} \\
\hline Electricity use in upgrading plant (water scrubber) & $\mathrm{MJ} / \mathrm{Nm}^{3}$ biogas & 0.4 & [64] \\
\hline Slippage in upgrading plant (amine scrubber) & $\%$ biogas & $0.10 \%$ & {$[64]$} \\
\hline Combined heat and power (CHP), electrical efficiency & MJ el./MJ biogas & $40.0 \%$ & [65] \\
\hline Combined heat and power (CHP), thermal efficiency & MJ heat/MJ biogas & $50.0 \%$ & {$[65]$} \\
\hline Transportation (lorry 16-32, Euro 5) & $\mathrm{grCO}_{2}$-eq/ton-km & 170 & EcoInvent 3 \\
\hline Transportation (lorry 3.5-7.5, Euro 5) & gr CO 2 -eq/ton-km & 210 & EcoInvent 3 \\
\hline Emission of methane from food waste in landfill & $\%$ of BMP/year & $5.0 \%$ & [66] \\
\hline Mineral $\mathrm{N}$ fertilizer & $\mathrm{kg} \mathrm{CO}{ }_{2}-\mathrm{eq} / \mathrm{kg}$ & 11.5 & EcoInvent 3 \\
\hline Mineral P fertilizer & $\mathrm{kg} \mathrm{CO}$-eq/kg & 4.8 & EcoInvent 3 \\
\hline Commercial pig feed & $\mathrm{grCO}_{2}-\mathrm{eq} / \mathrm{kg}$ & 500 & [67] \\
\hline Electricity for residential cooling system & MJ el./ton cooling & 3.0 & {$[68]$} \\
\hline Heat for centralized cooling & MJ in steam/ton cooling & 21.1 & [68] \\
\hline Chinese electricity mix & gr CO $2-e q / M J$ & 331 & {$[69,70]$} \\
\hline Natural gas, including combustion (China) & $\mathrm{gr} \mathrm{CO}_{2}$-eq/MJ & 195 & {$[69,70]$} \\
\hline Diesel, including combustion (China) & $\mathrm{grCO}_{2}$-eq/MJ & 237 & {$[69,70]$} \\
\hline
\end{tabular}


Table 5. $\mathrm{pH}, \mathrm{TS}$, and VS from food waste (FW) used in BMP test, and VS reduction at the end of the BMP test. Total biogas and methane yield after 63 days. A, B, C, D $=$ different restaurants $/$ canteens; 1 and 2 = sampling day.

\begin{tabular}{|c|c|c|c|c|c|c|c|c|c|c|}
\hline \multirow[t]{2}{*}{ Samples } & \multirow[t]{2}{*}{ TS (\%) (FW) } & \multirow{2}{*}{$\begin{array}{l}\text { VS (\% of } \\
\text { TS) (FW) }\end{array}$} & \multirow[t]{2}{*}{$\mathrm{pH}$} & \multirow{2}{*}{$\begin{array}{c}\text { VS } \\
\text { Reduction } \\
(\%)\end{array}$} & \multicolumn{2}{|c|}{$\begin{array}{l}\text { Total Biogas Yield } \\
\left(\mathrm{mL} / \mathrm{g} \mathrm{VS}_{\text {add }}\right)\end{array}$} & \multicolumn{2}{|c|}{$\begin{array}{c}\text { Methane Yield } \\
\text { (mL CH} 4 / g \text { VS add })\end{array}$} & \multicolumn{2}{|c|}{ Methane Content (\%) } \\
\hline & & & & & Mean & $\pm \mathrm{SD}$ & Mean & $\pm \mathrm{SD}$ & Mean & $\pm \mathrm{SD}$ \\
\hline A-1 & 28.3 & 77.5 & 5.49 & 55.4 & 803 & 134 & 355 & 13 & 43.4 & 1.9 \\
\hline B-1 & 27.8 & 78.2 & 5.06 & 51.1 & 845 & 69 & 272 & 8 & 41.2 & 1.8 \\
\hline $\mathrm{C}-1$ & 23.8 & 84.9 & 4.81 & 50.3 & 974 & 111 & 348 & 14 & 44.7 & 0.8 \\
\hline D-1 & 27.4 & 81.9 & 5.08 & 54.3 & 643 & 63 & 232 & 29 & 40.0 & 1.3 \\
\hline A-2 & 29.8 & 81.9 & 4.81 & 54.4 & 785 & 90 & 275 & 36 & 39.4 & 1.2 \\
\hline B-2 & 27.4 & 74.2 & 4.95 & 53.3 & 962 & 209 & 335 & 57 & 42.1 & 1.7 \\
\hline$C-2$ & 21.6 & 75.9 & 5.10 & 50.3 & 894 & 9 & 374 & 14 & 43.4 & 2.6 \\
\hline D-2 & 26.0 & 80.8 & 5.25 & 49.5 & 932 & 196 & 377 & 84 & 43.7 & 1.7 \\
\hline Mean & 26.5 & 79.4 & & & 855 & $136^{a}$ & $321^{b}$ & $43^{a}$ & 42.2 & 1.8 \\
\hline
\end{tabular}

${ }^{a}$ Mean is calculated using sample variance. ${ }^{b}$ Values for methane yield were not directly used in the simulation. Instead, biogas yield and methane content were used. 


\section{Food Waste Characteristics—Lab and Literature}

The characteristics of the substrate of food waste (kitchen waste) for biogas production (Table 5) revealed low $\mathrm{pH}$ values, between 4.81 and 5.49, TS between 21.6 and 29.8 (\%) and, VS between 74.2 and 84.9 (\%VS of TS). After 63 days of batch incubation (BMP), the calculation for VS reduction showed values between 50 and $55 \%$ (Table 5).

The composition of food waste (FW) depends on the food diet and consumption patterns; therefore, it varies in time and place. In general, the food waste in China is characterized by high moisture content: more than $60 \%$ in a southern city [71] and $92 \%$ in urban areas of Hangzhou City [49], with VS (\% of TS) around $87 \%$ and $80 \%$, respectively. The pH has the tendency to be acidic within a range of 3.6-7.0 [49,71,72]. The contents of organic components are high but vary in composition, while the contents of fat, protein and carbohydrate reported vary between $17-39 \%, 7-12 \%$ and $46-68 \%$, respectively [71]. The inorganic compounds, especially from kitchen waste, have a high level of salinity, with values between 1100 and $1200 \mathrm{mg} \mathrm{L}^{-1}$ of calcium and $95-110 \mathrm{mg} \mathrm{L}^{-1}$ of magnesium [73]. The elemental composition of the solid content (\% of TS) of carbon, hydrogen, oxygen, nitrogen, and sulfur are $46 \%, 7 \%, 2.5-3.8 \%, 2.5 \%$, and $0.3 \%$, respectively [ 49,72$]$.

The biogas production of the batch tests with food waste from Guangzhou University was $855 \pm 136 \mathrm{~mL} / \mathrm{g}$ VS, when the bio-methane production was $321 \pm 43 \mathrm{~mL} \mathrm{CH}_{4} / \mathrm{g}$ VS (Table 5 and Figure 3). The methane content in the raw biogas produced accounted for $42.2 \pm 1.8 \%$ (Table 5).
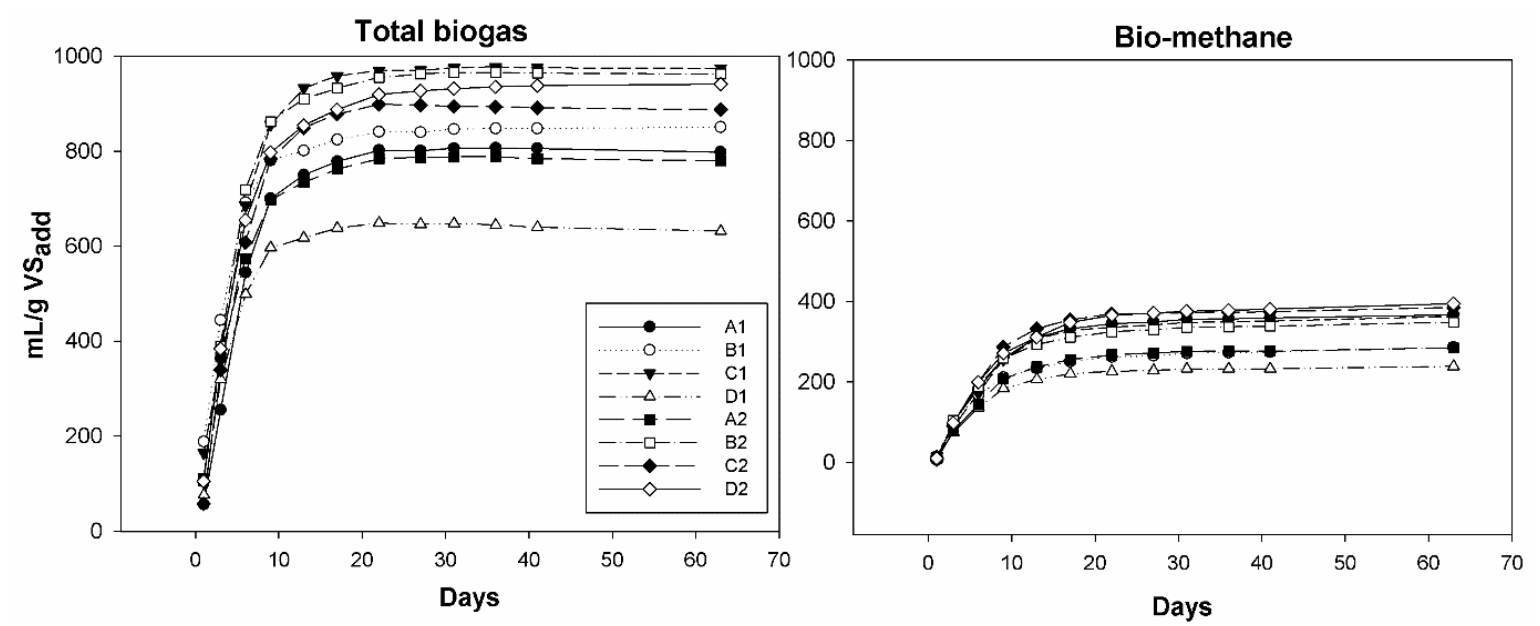

Figure 3. Cumulative curve of total biogas and bio-methane yield after 63 days. A, B, C, D = different restaurants/canteens; 1 and 2 = sampling day.

The results of bio-methane yield for Guangzhou University FW represented around 50\% of the theoretical values of 649 to $661 \mathrm{~mL} \mathrm{CH}_{4} / \mathrm{g}$ VS of FW from China [49,74], and those values can be an indication that some pretreatment is necessary to improve the methane production. However, the results are comparable with other studies, in different conditions, especially without pretreatment, as shown in Table 6. 
Table 6. Comparison of methane yield from different batch or reactor experiments with or without pretreatments of food waste in China.

\begin{tabular}{|c|c|c|c|c|c|}
\hline Reference & $\begin{array}{l}\text { Organic Substrate } \\
\text { (China) }\end{array}$ & Batch/Reactor & $\begin{array}{c}\text { Organic Loading } \\
\text { Rate (OLR) }(g \cdot V S / L)\end{array}$ & Pretreatment & $\begin{array}{l}\text { Methane Yield (mL } \\
\left.\mathrm{CH}_{4} / \mathrm{g} \mathrm{VS}_{\mathrm{add}}\right)\end{array}$ \\
\hline Present work & kitchen waste (KW) & Batch bottles & 2.50 & Untreated & $321 \pm 43$ \\
\hline \multirow{4}{*}{ [73] } & \multirow{4}{*}{ KW } & \multirow{4}{*}{$\begin{array}{l}\text { Anaerobic membrane } \\
\text { bioreactor }\end{array}$} & 4.7 & \multirow{4}{*}{$\begin{array}{l}\text { Sorting, crushing, oil extraction, solid-liquid } \\
\text { separation, and grid filtration processes }\end{array}$} & $250 \pm 25$ \\
\hline & & & 5.9 & & $308 \pm 21$ \\
\hline & & & 7.5 & & $331 \pm 18$ \\
\hline & & & 9.3 & & $358 \pm 13$ \\
\hline \multirow{5}{*}[72]{} & \multirow{5}{*}{ KW-liquid phase } & \multirow{5}{*}{ Batch bottles } & & Thermal hydrolysis $\left(120^{\circ} \mathrm{C}, 10 \mathrm{~min}\right)$ & 690 \\
\hline & & & & Thermal hydrolysis $\left(120^{\circ} \mathrm{C}, 30 \mathrm{~min}\right)$ & 840 \\
\hline & & & & Thermal hydrolysis $\left(120^{\circ} \mathrm{C}, 40 \mathrm{~min}\right)$ & 910 \\
\hline & & & & Thermal hydrolysis $\left(120^{\circ} \mathrm{C}, 50 \mathrm{~min}\right)$ & 870 \\
\hline & & & & Thermal hydrolysis $\left(120^{\circ} \mathrm{C}, 60 \mathrm{~min}\right)$ & 700 \\
\hline \multirow{8}{*}{ [74] } & \multirow{8}{*}{$\begin{array}{l}\text { Oil seed rape straw } \\
\text { (ORS), kitchen waste } \\
\text { (KW) and duck } \\
\text { droppings (DD) }\end{array}$} & \multirow{8}{*}{$\begin{array}{l}\text { Two phase anaerobic } \\
\text { digestion system: } 1= \\
\text { hydrolytic-acidification } \\
\text { reactor, and } 2= \\
\text { bio-gasification } \\
\text { reactor }\end{array}$} & 60 & $\begin{array}{l}\text { Untreated. } \\
\text { Oil seed rape straw-ORS }=100 \%\end{array}$ & 132 \\
\hline & & & 60 & $\begin{array}{l}\text { Untreated. } \\
\text { Kitchen waste-KW = 100\% }\end{array}$ & 336 \\
\hline & & & 60 & $\begin{array}{c}\text { Untreated. } \\
\text { Duck droppings-DD = 100\% }\end{array}$ & 159 \\
\hline & & & 60 & $\begin{array}{c}\text { Co-digestion. } \\
\text { ORS: KW: DD ratios }=\text { 50:50:0 }\end{array}$ & 318 \\
\hline & & & 60 & Co-digestion. 50:0:50 & 171 \\
\hline & & & 60 & Co-digestion. 50:40:10 & 375 \\
\hline & & & 60 & Co-digestion. 50:25:25 & 276 \\
\hline & & & 60 & Co-digestion. 50:10:40 & 231 \\
\hline
\end{tabular}


Table 6. Cont.

\begin{tabular}{|c|c|c|c|c|c|}
\hline Reference & $\begin{array}{c}\text { Organic Substrate } \\
\text { (China) }\end{array}$ & Batch/Reactor & $\begin{array}{l}\text { Organic Loading } \\
\text { Rate }(\text { OLR) }(\mathrm{g} \cdot \mathrm{VS} / \mathrm{L})\end{array}$ & Pretreatment & $\begin{array}{c}\text { Methane Yield (mL } \\
\left.\mathrm{CH}_{4} / \mathrm{g} \mathrm{VS}_{\mathrm{add}}\right)\end{array}$ \\
\hline \multirow{13}{*}{ [49] } & \multirow{13}{*}{ KW } & \multirow{13}{*}{ Batch bottles } & & Untreated & 388 \\
\hline & & & & $500 \mathrm{rpm}, 20 \mathrm{~min}, 100^{\circ} \mathrm{C}$ & 425 \\
\hline & & & & $500 \mathrm{rpm}, 20 \mathrm{~min}, 120^{\circ} \mathrm{C}$ & 458 \\
\hline & & & & $500 \mathrm{rpm}, 20 \mathrm{~min}, 140^{\circ} \mathrm{C}$ & 512 \\
\hline & & & & $500 \mathrm{rpm}, 20 \mathrm{~min}, 160^{\circ} \mathrm{C}$ & 375 \\
\hline & & & & $500 \mathrm{rpm}, 20 \mathrm{~min}, 180^{\circ} \mathrm{C}$ & 375 \\
\hline & & & & $500 \mathrm{rpm}, 20 \mathrm{~min}, 200^{\circ} \mathrm{C}$ & 355 \\
\hline & & & & $500 \mathrm{rpm}, 140{ }^{\circ} \mathrm{C}, 5 \mathrm{~min}$ & 424 \\
\hline & & & & $500 \mathrm{rpm}, 140^{\circ} \mathrm{C}, 10 \mathrm{~min}$ & 445 \\
\hline & & & & $500 \mathrm{rpm}, 140^{\circ} \mathrm{C}, 15 \mathrm{~min}$ & 488 \\
\hline & & & & $501 \mathrm{rpm}, 140^{\circ} \mathrm{C}, 20 \mathrm{~min}$ & 512 \\
\hline & & & & $500 \mathrm{rpm}, 140^{\circ} \mathrm{C}, 25 \mathrm{~min}$ & 512 \\
\hline & & & & $500 \mathrm{rpm}, 140^{\circ} \mathrm{C}, 30 \mathrm{~min}$ & 473 \\
\hline
\end{tabular}




\section{Socio-Technical Context}

The interviews provided a better understanding of the existing food waste management in Guangzhou in general, and more specifically regarding Xiaoguwei Island. They also gave information about the previous handling of food waste and ongoing developments as well as some input on expected future development.

Food waste has traditionally been used as animal food in Guangzhou, which according to the respondents may involve serious health and environmental risks. As a consequence, there has been a shift towards landfilling and incineration of food waste. In addition to landfills, the food waste is usually delivered to food waste treatment or refuse processing plants. Guangzhou has four landfills including the Xing Feng landfill, Lee Hang landfill, Datianshian landfill and Huo Shao Gang landfill. However, there are still examples of treatments of the food waste for use as animal feed, such as cooking and other simple processing. As one of the respondents [75] indicated, about 200 tons of food waste are collected each day in Guangzhou-this is about $10 \%$ of the total amount of food waste generated in the city, which is about 2000 tons per day-for resource recovery purposes. This collected share is mainly transported to the Datianshan plant. However, the interviewees also mentioned conflicts over the logistics and transport of kitchen waste, as a significant share of this is sold informally to non-governmental actors that are responsible for the collection and transportation of kitchen waste. It was noted that up to $90 \%$ of the food waste might actually end up on the "black market" [76].

Food waste on Xiaoguwei Island is mainly generated by the canteens of the ten universities, and the catering industry in two shopping centers-South Pavilion Village and North Pavilion Village [76]. Every other day, about half of the food waste from Xiaoguwei Island is transported from the island to the Datianshan waste treatment plant, where aerobic processes are used to produce biofertilizer/soil conditioners. The rest of the food waste is either sold to pig farms or sent to landfill. However, it was also stated [77] that the collection and treatment methods are not standardized, because small manufacturers and others involved lack sufficient qualifications and competencies. Nevertheless, some informal treatments are performed to produce feed with cooking and other simple processing, and a small amount is composted in small scale.

The director of the Guangzhou Datianshan kitchen waste plant [78] stated that there is currently no biogas plant in operation in Guangzhou. Reasons for this situation were in his view that the anaerobic digestion process can be too slow, and that the digestate presently could not be used as a fertilizer. Moreover, he expressed that biogas production alone could not cover the operational costs of a biogas plant, and consequently a significant share of food waste needed to be landfilled or incinerated.

Although interviewees were not aware of any current biogas plant in use, they pointed out that there are projects under construction. The expected short-term level of biogas production would nevertheless be very low because actors had a strong belief in the current system of food waste treatment.

However, there are several improvements of current policy instruments (e.g., laws, regulations, and management procedures) under way in Guangzhou to improve the food waste disposal business [78]. Kitchen waste regulations are included in the "Regulation of Guangdong municipality", which specifies the handling and disposal of municipal and rural wastes. These planned improvements provide a technical basis for the design, construction and operation of kitchen waste treatment plants. They are also expected to reduce current conflicts with garbage collectors and the sale of food waste on the black market.

As the interviews about the handling of food waste make clear, the main reasons for the underutilization of the biogas production potential lie rather in socio-economic and cultural contexts than in limited technical feasibility. Among potential factors contributing to this are strong traditions in the way food waste is being used, lacking positive perceptions of waste-to-biogas processes (e.g., not part of visions and expectations of a "modern" energy system with sustainable resource use and low carbon emissions), insufficient competences and knowledge of stakeholders (plant construction and 
operation, waste collection, municipal administration and policy), lacking support from state and municipality for building a functioning waste-to-biogas system, or insufficient regulatory structures regarding waste separation and collection as well as operation of biogas plants. However, the current changes in the policy system that are under way can improve the institutional conditions for increased biogas production from food waste.

\section{Biogas Potential and Climate Performance}

The collected information was used to establish a "base scenario", with essential information about the existing food waste management on Xiaoguwei Island (Figure 4). It was estimated that 15,000 tons of food waste was generated each year, consisting of 5000 tons/year from the university canteens and 10,000 tons/year from the other municipal sources such as catering services and hotels. Despite of interviews and access to some records, this figure should be regarded as a rough estimation, due to insufficient information. For simplicity, it was assumed that "other sources" (such as catering companies and hotels) had similar collection systems and food waste compositions as the university canteens. However, some hotels on the island serve a broader range of dishes than these canteens.
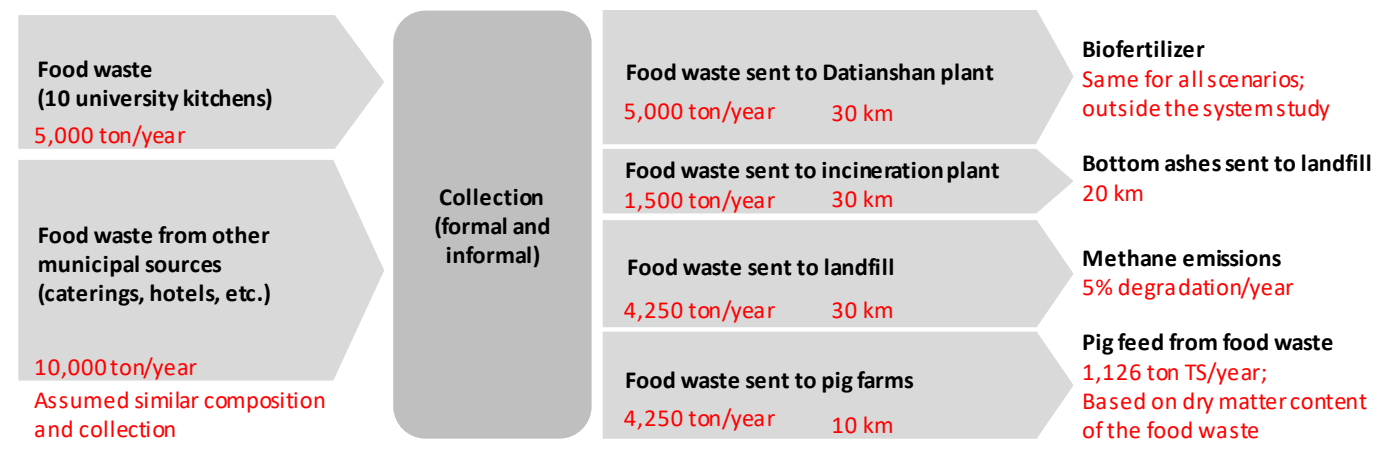

Figure 4. Overview of the main processes and flows in Scenario 0 (Base, representing the existing food waste management situation on the island.

The amount of food waste that is transported to the Datianshan plant was relatively well specified, but being a well-established solution, this part of the food waste was not considered for biogas production. Instead, the shares sent to landfill, pig farms, and incineration were in focus and varied (see Table 3).

The development scenarios were all defined based on the "base scenario", involving different shares of food waste to different treatments (defined in Table 3). Figures 5-7 show the results of system modeling. The included uncertainties are due to uncertainties in the amount of biomethane that can be produced-see Section 3. Other types of uncertainties (such as uncertainties in the available amount of food waste, possible pretreatments required, or distances) are excluded in these results.

If we assume the average values for dry matter content, organic matter content, biogas yield, and methane content of biogas from the lab analysis, depending on how the 15,000 tons of food waste are treated (considering different scenarios involving lower or higher degrees of biogas production), it would be possible to deliver $0.1-0.6$ million $\mathrm{Nm}^{3}$ biomethane each year, and potentially replace 5-36 tons of nitrogen fertilizer, and 2-12 tons of phosphorous fertilizer. If we consider a more realistic scenario such as $B G$ real, these potentials become 0.3 million $\mathrm{Nm}^{3}$ biomethane, 18 tons of nitrogen fertilizer, and 6 tons of phosphorous fertilizer. As a result of utilizing these amounts of biogas and biofertilizers, about 1780 tons of $\mathrm{CO}_{2}$-eq greenhouse gas emissions are avoided. 


\section{Greenhouse gas emissions per ton food waste treated}

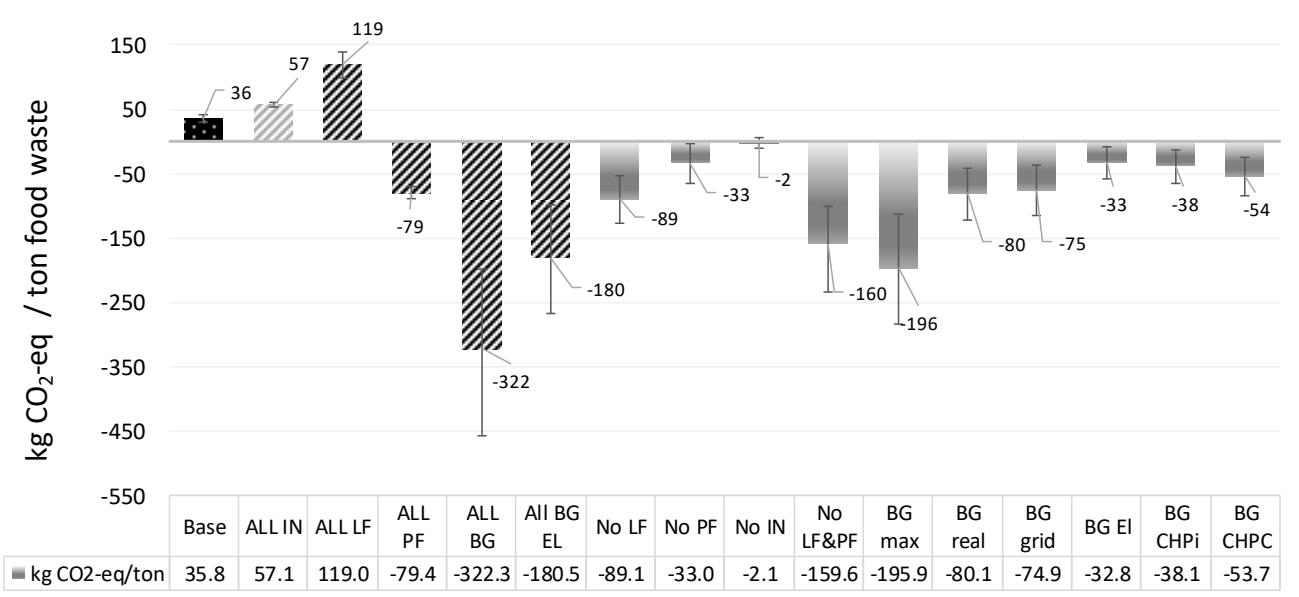

Figure 5. Comparison of the greenhouse gas (GHG) emissions of the studied scenarios per ton of food waste treated.

Contribution of the main activities to total greenhouse gas emissions in different scenarios (per ton food waste treated)

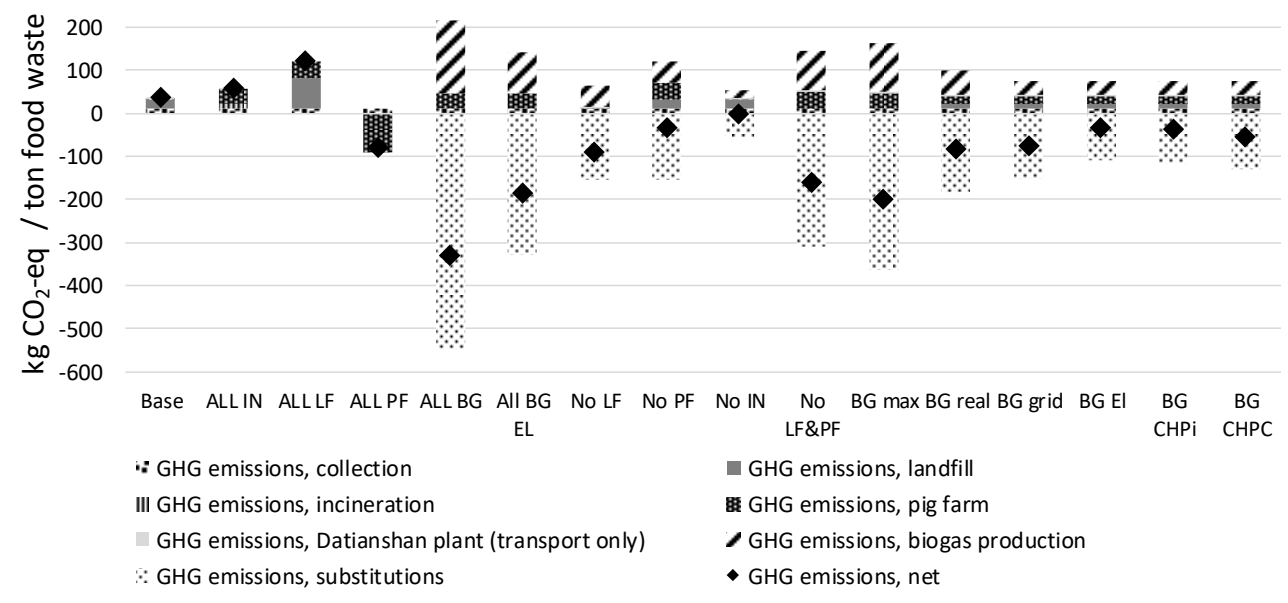

Figure 6. Comparison of the GHG emissions of the studied scenarios per ton of food waste treated. The "diamonds" represent the net emissions (sum of emissions from treatment and substitutions).

Figure 5 shows the greenhouse gas (GHG) emissions for treating one ton of food waste. In all scenarios, the production of biogas from food waste led to a net reduction of GHG emissions compared to the base scenario. Looking at the impacts of different technologies (ALL IN, ALL LF, ALL PF, ALL BG, and BG EL), it can be seen that using food waste for feeding pigs or producing biogas leads to lower GHG emissions than sending it to incineration or landfill. Upgrading the biogas leads to a greater reduction of GHG emissions than using raw biogas to produce electricity. This is based on the assumptions (see Table 4) regarding the Chinese electricity mix, natural gas, and diesel, as well as gas to electricity conversion efficiency.

The contribution of different treatment methods, in each scenario, to the total GHG emissions, are shown in Figure 6. Depending on the output of each scenario, the substitution effects include the effect of substituting mineral fertilizers with the nutrient content of the produced digestate, the effect of substituting natural gas by upgraded biogas injected into the gas grid, the effect of substituting diesel with upgraded biogas which can be used as transportation fuel, substituting Chinese average electricity by the amount of electricity produced from biogas, and substituting electricity as a result of heat recovery from biogas $\mathrm{CHP}$ and using the heat in decentralized cooling system. 


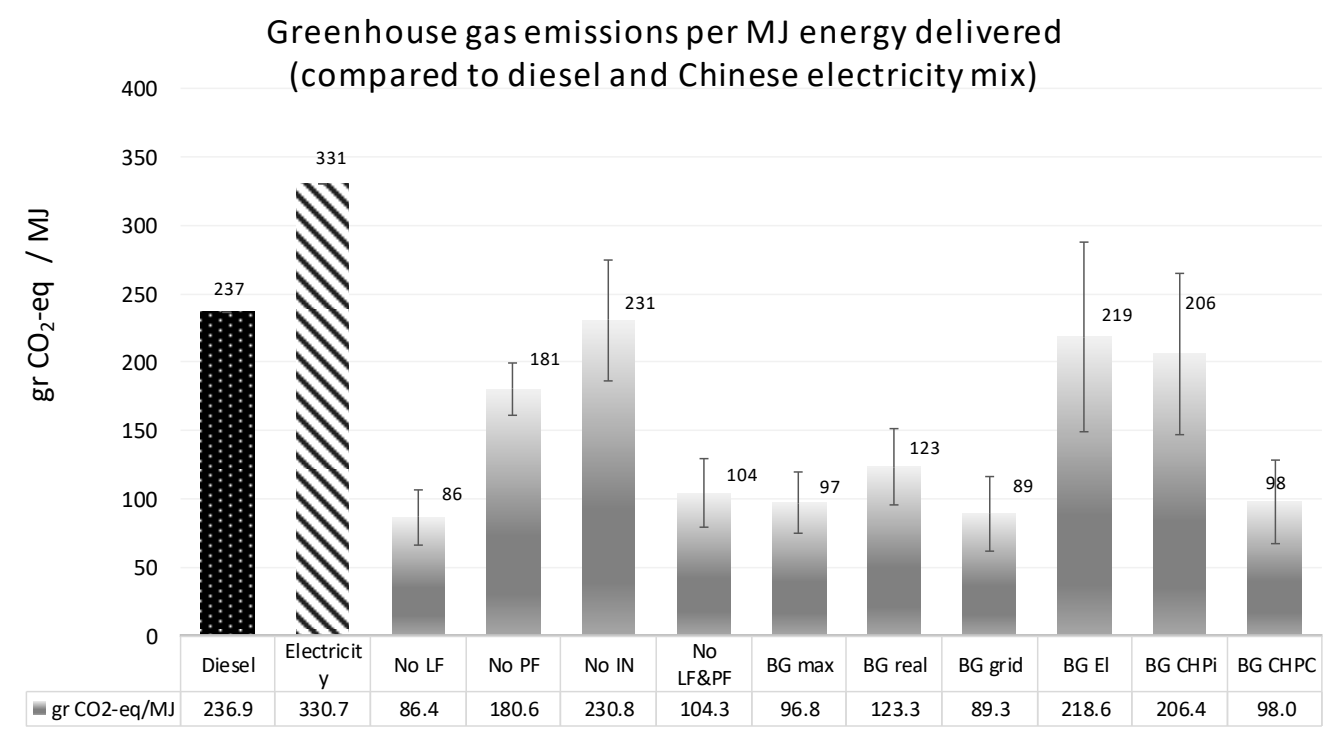

Figure 7. Comparison of the GHG emissions of the studied scenarios per MJ energy delivered (either in the form of raw or upgraded biogas, heating, or cooling).

In those scenarios that involve biogas production, the cradle-to-gate results expressed in GHG emissions per MJ of energy delivered (energy from biomethane, either in the form of raw biogas, upgraded biogas, electricity, heating, or cooling) are presented in Figure 7. Here, no substitution effects from producing biogas are considered; instead, the GHG emissions of the delivered energy are compared with those of diesel and electricity. The substitution effect of replacing mineral fertilizers by digestate is considered.

These results can be compared with a few published peer-reviewed system studies that use life-cycle assessment as their main approach. Dong et al. [79] compared different ways of handling municipal solid waste (MSW) in a pilot project in Hangzhou, China, in which MSW was source-separated. They concluded that source-separation and anaerobic digestion of the organic fraction could lead to a significant reduction of greenhouse gas emissions compared to the existing waste management system, which is mainly based on landfilling and incineration. Woon et al. [80] compared different utilization pathways of using biogas that is produced from food waste, namely, electricity and heat production, using biogas as city gas, and upgrading it to be used in vehicles. They concluded that the highest level of reducing greenhouse gas emissions can be achieved if biogas is upgraded and used as vehicle fuel, leading to a net savings of about $100 \mathrm{~kg} \mathrm{CO}_{2}$-eq per ton of food waste. Jin et al. [81] studied an integrated food waste treatment system involving anaerobic digestion and thermal treatment, located in the city of Suzhou (Jiangsu Province, in eastern China). Their study focused on the performance of this treatment technology, so their system did not include collection, transportation, and utilization of the products. The received food waste was pretreated; the extracted oil was used to produce bio-diesel, while the solid part was sent to the biogas plant. The produced bio-diesel and biogas were used to create electricity and heat. The digestate was centrifuged, and its liquid fraction was discharged to the municipal sewer system, while the solid fraction was incinerated. The study did not include the effect of diverting food waste from other treatment methods to biogas production. It is estimated that the greenhouse gas emissions of the studied treatment method are $97 \mathrm{~kg} \mathrm{CO}$-eq/ton treated waste. Chen et al. [82] performed a form of multiple-criteria decision-making analysis of the same technological concept in order to evaluate its environmental and economic benefits as well as energy use. Liu et al. [83] compared a few scenarios for the treatment of municipal solid wastes in China and concluded that incineration could lead to the highest reduction of greenhouse emissions. This was partly due to their assumptions that $5 \%$ of the produced biogas is inevitably leaked during production, and that the produced digestate cannot be used but landfilled-leading to more $\mathrm{CH}_{4}$ emissions. In another study, $\mathrm{Xu}$ et al. [84] compared three scenarios for food waste treatment 
in China: landfilling, producing biogas from a mixture of food waste and sewage sludge, or producing biogas just from food waste. This study excluded digestate treatment and application from the scope of the study. Nevertheless, it showed that producing biogas from food waste was the best option and depending on the assumption regarding the substituted electricity, could lead to a reduction of 331 to $481 \mathrm{~kg} \mathrm{CO}$-eq emissions per ton of food waste.

Although these studies have very different setups and foci, their overall results are in most cases very close to the results of this system study and seem to support it.

\section{Concluding Discussion}

This article presents a study of the conditions for biogas solutions in the Guangzhou megacity context in China, focusing on food waste and Xiaoguwei Island with a population of about 250,000 people. It is based on a transdisciplinary approach, with the ambition to provide information about three key types of conditions. The first is the potential, where interviews, literature studies and lab analysis have been used to estimate the amount of food waste and determine its characteristics. The second regards feasibility, for which workshops and interviews have been essential to learn about the socio-technical context (e.g., about drivers and barriers). The third is performance, where life-cycle assessment has been used to investigate the climate impact of different food waste management scenarios involving biogas production. Combined, these three parts constitute a generic transdisciplinary approach that can be used to systematically explore conditions for biogas solutions, for example in a (mega)city. However, it must be emphasized that our study should be seen as an initial screening to get an overall understanding; more in-depth studies are required before any implementation. For example, it was challenging to map the food waste flows related to Xiaoguwei Island, indicating that it would be very demanding for the whole megacity. In addition, many actors are involved, with different roles, understanding, terminology, etc., of which we have only interacted with a few. Access to sufficient information of good quality can be difficult, either because such information is not available, is restricted due to organizational considerations, or in the case of international collaborations is difficult to obtain and understand due to language barriers.

The findings show that there is a significant food waste potential on Xiaoguwei Island, one that could be used to produce biogas and biofertilizers. For example, based on the estimated yearly 15,000 tons of food waste, the scenario named $B G$ real (see Table 3) provides about 0.3 million $\mathrm{Nm}^{3}$ biomethane, 18 tons of nitrogen fertilizer, and 6 tons of phosphorous fertilizer. This would involve a reduction of greenhouse gas emissions of about 1780 tons of $\mathrm{CO}_{2}$-eq each year. It can be noted that the population of Xiaoguwei Island represents about $\%$ of the Guangzhou population, which can be used to get a rough estimate of the potential and performance for the whole megacity (regarding biogas from food waste). The GHG emissions reduction is the highest in case of diversion from landfilling, and the least in case of diversion from incineration; nevertheless, both can potentially lead to recovery and recycling of significant amounts of nutrients. Diversion of food waste from pig farms to biogas plants can also lead to a net reduction of GHG emissions, but the impact on the wider system is more complicated and should be further investigated. About $40 \%$ of Chinese grain production is allocated to animal feeding [45]. This share can be reduced if food waste is used in a safe way as animal feed. Indeed, the practice of feeding animals with food waste has been historically common in China, but since the outbreak of the SARS disease in the early 2000s several cities banned it to reduce the risk to health and environment. Nevertheless, the practice has been generally continued [45], and is also a concern in Guangzhou as it was highlighted during the interview study. So the question remains if there can be ways to safely and efficiently use food waste as animal feed and avoid grain use (for a few related studies, see: [84-86]), or it is better to divert them to biogas production and use the energy and the digestate (as biofertilizer). This point is also related to the fact that Guangzhou and its surrounding regions are highly urbanized, meaning that it can be challenging to establish efficient biofertilizer solutions in cooperation with agriculture, as it may require special technical, organizational, and legal arrangements. This should be further investigated. This study 
also leads to a better understanding of the socio-technical conditions regarding Xiaoguwei Island and the broader context. The current conditions are not very favorable for the implementation of biogas solutions, mainly due to socio-economic and cultural aspects. For example, alternative solutions such as informal treatment of food waste or landfilling are common and relatively cheap. Furthermore, there seem to be strong traditions in the way food waste is being used; a lack of positive perceptions of waste-to-biogas processes; insufficient competences; and inadequate support (economic or other types) from the state and city level to establish central large-scale waste-to-biogas systems, including regulations leading to a suitable food waste management system. However, several signs of improved conditions have been noted, for example, the more supportive policy instruments mentioned in the introduction and by several respondents that may help in overcoming some of the identified socio-technical and economic challenges. However, in addition to policy instruments, regional network building, learning processes, and the shift of perceptions are also important. According to Geels and Raven [87] referring to [88], biogas solutions belong to a certain type of technologies whose main challenge is to make sure that several different components are working together. This makes them relatively complex because they require collaboration among several types of actors, ranging from large municipal organizations to small farmers [89]. Consequently, the successful implementation of biogas solutions depends on an increased and continuous level of collaboration among a diverse set of actors and a significant increase in their knowledge of biogas production systems. This is a point that has been shown in some of the countries and regions that have experienced the successful implementation of biogas solutions. For example, a review of the historical development of biogas solutions in Denmark since the 1970s highlighted the importance of bottom-up strategies that promoted interaction and learning among various actors. In addition, the continuous development of biogas solutions was enabled by a dedicated social network and long-term socio-political stimulations [90]. Also, a study of the historical development of biogas production in Linköping, Sweden from 1976 to 2015 concluded that despite the importance of a supportive national policy system, the main driver for development had been a group of local actors-system builders-who constantly steered the process and could mobilize resources [91]. These examples could be of relevance for biogas implementation on Xiaoguwei Island-population-wise having a similar scale as medium-sized cities in the mentioned Nordic countries-but probably also for the whole city of Guangzhou.

Author Contributions: Conceptualization, R.F., J.A. and A.E.-P.; Data curation, R.F., J.A., A.B., Y.G., M.K., Y.L. (Yonghui Liu), Y.L. (Yuxian Liu), L.S.M.M., A.E.-P., K.T., S.S.Y. and F.Z.; Formal analysis, R.F., J.A., A.B., L.S.M.M., A.E.-P., H.R., K.T. and S.S.Y.; Funding acquisition, J.A., A.E.-P., Y.G., A.B., M.K., H.R.; Methodology, R.F., J.A., A.B., Y.G., L.S.M.M., A.E.-P., H.R., K.T., S.S.Y.; Project administration, J.A., A.E.-P., Y.G.; Writing—original draft, R.F., J.A., A.B., Y.G., M.K., L.S.M.M., A.E.-P., H.R., K.T., S.S.Y.; Writing-review and editing, R.F., J.A., A.B., Y.G., M.K., L.S.M.M., A.E.-P., H.R., K.T., S.S.Y.

Funding: This research was funded by the Linköping University-Guangzhou University Research Center on Urban Sustainable Development, in turn funded by Guangzhou City and the Training Program for Excellent Young Teachers in Guangdong Universities (YQ2015125).

Acknowledgments: The overall purpose of this research was to contribute to increased knowledge about the potential and conditions for biogas and biofertilizer production in Guangzhou. We thank Linköping University-Guangzhou University Research Center on Urban Sustainable Development for their support and funding of this project (see Funding).

Conflicts of Interest: The authors declare no conflict of interest.

\section{References and Notes}

1. Naughton, B. Growing Out of the Plan: Chinese Economic Reform, 1978-1993; Cambridge University Press: Cambridge, UK, 1996.

2. Chen, M.; Liu, W.; Tao, X. Evolution and assessment on China's urbanization 1960-2010: Under-urbanization or over-urbanization? Habitat Int. 2013, 38, 25-33. [CrossRef]

3. Hsieh, S.-C. Analyzing urbanization data using rural-urban interaction model and logistic growth model. Comput. Environ. Urban Syst. 2014, 45, 89-100. [CrossRef] 
4. Zhang, L.X.; Chen, B.; Yang, Z.F.; Chen, G.Q.; Jiang, M.M.; Liu, G.Y. Comparison of typical mega cities in China using emergy synthesis. Commun. Nonlinear Sci. Numer. Simul. 2009, 14, 2827-2836. [CrossRef]

5. Chen, H.; Ganesan, S.; Jia, B. Environmental challenges of post-reform housing development in Beijing. Habitat Int. 2005, 29, 571-589. [CrossRef]

6. Chan, C.K.; Yao, X. Air pollution in mega cities in China. Atmos. Environ. 2008, 42, 1-42. [CrossRef]

7. Chang, D.; Song, Y.; Liu, B. Visibility trends in six megacities in China 1973-2007. Atmos. Res. 2009, 94, 161-167. [CrossRef]

8. Kumar, P.; Jain, S.; Gurjar, B.R.; Sharma, P.; Khare, M.; Morawska, L.; Britter, R. New Directions: Can a “blue sky" return to Indian megacities? Atmos. Environ. 2013, 71, 198-201. [CrossRef]

9. Peng, X.; Wang, Z.; Kuang, W.; Tan, J.; Li, K. A preliminary study on the occurrence and behavior of sulfonamides, ofloxacin and chloramphenicol antimicrobials in wastewaters of two sewage treatment plants in Guangzhou, China. Sci. Total Environ. 2006, 371, 314-322. [CrossRef] [PubMed]

10. Sun, G.; Michelsen, A.M.; Sheng, Z.; Fang, A.F.; Shang, Y.; Zhang, H. Featured Collection Introduction: Water for Megacities-Challenges and Solutions. J. Am. Water Resour. Assoc. 2015, 51, 585-588. [CrossRef]

11. Cai, M.; Zou, J.; Xie, J.; Ma, X. Road traffic noise mapping in Guangzhou using GIS and GPS. Appl. Acoust. 2015, 87, 94-102. [CrossRef]

12. Goines, L.; Hagler, L. Noise pollution: A modern plague. South. Med. J.-Birm. Ala. 2007, 100, 287. [CrossRef]

13. Kennedy, C.A.; Stewart, I.; Facchini, A.; Cersosimo, I.; Mele, R.; Chen, B.; Uda, M.; Kansal, A.; Chiu, A.; Kim, K.; et al. Energy and material flows of megacities. PNAS 2015, 112, 5985-5990. [CrossRef]

14. Wilson, D.C.; Velis, C.A. Cities and waste: Current and emerging issues. Waste Manag. Res. 2014, 32, 797-799. [CrossRef] [PubMed]

15. Dent, C.M. China's renewable energy development: Policy, industry and business perspectives. Asia Pacif. Bus. Rev. 2015, 21, 26-43. [CrossRef]

16. Fewsmith, J. China in 2007: The politics of leadership transition. Asian Surv. 2008, 48, 82-96. [CrossRef]

17. Araújo, K.; Mahajan, D.; Kerr, R.; Silva, M. da Global Biofuels at the Crossroads: An Overview of Technical, Policy, and Investment Complexities in the Sustainability of Biofuel Development. Agriculture 2017, 7, 32. [CrossRef]

18. Banerjee, R.; Benson, S.M.; Bouille, D.H.; Brew-Hammond, A.; Cherp, A.; Coelho, S.T.; Emberson, L.; Figueroa, M.J.; Grubler, A.; Jaccard, M.; et al. Global Energy Assessment; Cambridge University Press: Cambridge, UK; New York, NY, USA; The International Institute for Applied Systems Analysis: Laxenburg, Austria; Cambridge, UK, 2012; p. 1865.

19. Christensen, A.; Hobbs, B. A model of state and federal biofuel policy: Feasibility assessment of the California Low Carbon Fuel Standard. Appl. Energy 2016, 169, 799-812. [CrossRef]

20. European Commission. A Strategy For smart, Sustainable and Inclusive Growth. Communication from the Commission Europe 2020; COM(2010) 2020 Final; European Commission: Brussels, Belgium; Luxembourg, 2010.

21. Eurostat; Savova, I. Europe 2020 Strategy_Towards a Smarter, Greener and More Inclusive EU Economy? European Union: Luxembourg; Brussels, Belgium, 2012; p. 11.

22. Kampman, B.; Leguijt, C.; Scholten, T.; Tallat-Kelpsaite, J.; Brückmann, R.; Maroulis, G.; Lesschen, J.P.; Meesters, K.; Sikirica, N.; Elbersen, B. Optimal Use of Biogas from Waste Streams. An Assessment of the Potential of Biogas from Digestion in the EU beyond 2020; European Commission: Brussels, Belgium; Luxembourg, 2016.

23. Angelidaki, I.; Karakashev, D.; Batstone, D.J.; Plugge, C.M.; Stams, A.J.M. Chapter sixteen—Biomethanation and Its Potential. In Methods in Enzymology; Rosenzweig, A.C., Ragsdale, S.W., Eds.; Methods in Methane Metabolism, Part A; Academic Press: Cambridge, MA, USA, 2011; Volume 494, pp. 327-351. ISBN 0076-6879.

24. Weiland, P. Production and energetic use of biogas from energy crops and wastes in Germany. Appl. Biochem. Biotechnol. 2003, 109, 263-274. [CrossRef]

25. Svensson, M.; Baxter, D.; Drosg, B.; Bochmann, G.; McCabe, B.; Toyoma, J.; Al Seadi, T.; Rasi, S.; Theobald, O.; Bastide, G.; et al. IEA Bioenergy Task 37-Country Reports Summary 2015; IEA Bioenergy Task 37; IEA: Paris, France, 2015.

26. Ammenberg, J.; Feiz, R. Assessment of feedstocks for biogas production, part II-Results for strategic decision making. Resour. Conserv. Recycl. 2017, 122, 388-404. [CrossRef]

27. Feiz, R.; Ammenberg, J. Assessment of feedstocks for biogas production, part I-A multi-criteria approach. Resour. Conserv. Recycl. 2017, 122, 373-387. [CrossRef] 
28. Gu, L.; Zhang, Y.-X.; Wang, J.-Z.; Chen, G.; Battye, H. Where is the future of China's biogas? Review, forecast, and policy implications. Pet. Sci. 2016, 13, 604-624. [CrossRef]

29. Jiang, X.; Sommer, S.G.; Christensen, K.V. A review of the biogas industry in China. Energy Policy 2011, 39, 6073-6081. [CrossRef]

30. Scarlat, N.; Dallemand, J.-F.; Fahl, F. Biogas: Developments and perspectives in Europe. Renew. Energy 2018, 129, 457-472. [CrossRef]

31. Chen, B.; Hayat, T.; Alsaedi, A. History of Biogas Production in China. In Biogas Systems in China; Springer: Berlin/Heidelberg, Germany, 2017; pp. 1-15, ISBN 978-3-662-55496-8.

32. De Clercq, D.; Wen, Z.; Gottfried, O.; Schmidt, F.; Fei, F. A review of global strategies promoting the conversion of food waste to bioenergy via anaerobic digestion. Renew. Sustain. Energy Rev. 2017, 79, 204-221. [CrossRef]

33. Kougias, P.G.; Angelidaki, I. Biogas and its opportunities-A review. Front. Environ. Sci. Eng. 2018, 12, 1-12. [CrossRef]

34. Gosens, J.; Kåberger, T.; Wang, Y. China's next renewable energy revolution: Goals and mechanisms in the 13th Five Year Plan for energy. Energy Sci. Eng. 2017, 5, 141-155. [CrossRef]

35. Ghisellini, P.; Cialani, C.; Ulgiati, S. A review on circular economy: the expected transition to a balanced interplay of environmental and economic systems. J. Clean. Prod. 2016, 114, 11-32. [CrossRef]

36. MOHURD. Compulsory Waste Classification System (Exposure Draft); General Office of the National Development and Reform Commission (NDRC) and Ministry of Housing and Urban-Rural Development (MOHURD): Beijing, China, 2016.

37. State Council Notice on Opinions about Further Improvement of MSW Treatment; General Office of State Council: Beijing, China, 2011.

38. State Council Opinions on Strengthen Management of Waste Cooking Oil and Restaurant Waste; General Office of State Council: Beijing, China, 2010.

39. Nelles, M.; Nassour, A.; Naas, A.E.; Lemke, A.; Morscheck, G.; Schüch, A.; He, P.; Lü, F.; Shao, L.; Zhang, H. Recycling and Recovery of the Biogenic Fractions from Municipal Solid Waste in the PR of China; University of Rostock: Rostock, Germany, 2017; ISBN 978-3-86009-453-2.

40. Atelge, M.R.; Krisa, D.; Kumar, G.; Eskicioglu, C.; Nguyen, D.D.; Chang, S.W.; Atabani, A.E.; Al-Muhtaseb, A.H.; Unalan, S. Biogas Production from Organic Waste: Recent Progress and Perspectives. Waste Biomass Valor 2018. [CrossRef]

41. Su, Y.; Zhang, P.; Su, Y. An overview of biofuels policies and industrialization in the major biofuel producing countries. Renew. Sustain. Energy Rev. 2015, 50, 991-1003. [CrossRef]

42. Chaolin, G.U.; Liya, W.U.; Cook, I. Progress in research on Chinese urbanization. Front. Archit. Res. 2012, 1, 101-149. [CrossRef]

43. Zhou, H.; Meng, A.; Long, Y.; Li, Q.; Zhang, Y. An overview of characteristics of municipal solid waste fuel in China: Physical, chemical composition and heating value. Renew. Sustain. Energy Rev. 2014, 36, 107-122. [CrossRef]

44. Chinese MEP. Annual Report on Prevention and Control of Pollution by Municipal Solid Wastes in Large and Medium Cities 2016; Ministry of Environmental Protection of the People's Republic of China: Beijing, China, 2016. (In Chinese)

45. Dou, X.S. Food waste generation and its recycling recovery: China's governance mode and its assessment. Fresen. Environ. Bull. 2015, 24, 1474-1482.

46. Gu, B.; Jiang, S.; Wang, H.; Wang, Z.; Jia, R.; Yang, J.; He, S.; Cheng, R. Characterization, quantification and management of China's municipal solid waste in spatiotemporal distributions: A review. Waste Manag. 2017, 61, 67-77. [CrossRef]

47. National Bureau of Statistics China. China Statistical Yearbook 2014; National Bureau of Statistics China: Beijing, China, 2015.

48. Butt, T.E.; Gouda, H.M.; Baloch, M.I.; Paul, P.; Javadi, A.A.; Alam, A. Literature review of baseline study for risk analysis-The landfill leachate case. Environ. Int. 2014, 63, 149-162. [CrossRef]

49. Ding, L.; Cheng, J.; Qiao, D.; Yue, L.; Li, Y.-Y.; Zhou, J.; Cen, K. Investigating hydrothermal pretreatment of food waste for two-stage fermentative hydrogen and methane co-production. Bioresour. Technol. 2017, 241, 491-499. [CrossRef] [PubMed] 
50. Komilis, D.; Kissas, K.; Symeonidis, A. Effect of organic matter and moisture on the calorific value of solid wastes: An update of the Tanner diagram. Waste Manag. 2014, 34, 249-255. [CrossRef]

51. Sokhansanj, S. The effect of moisture on heating values. In Biomass Energy Data Book; Oak Ridge National Laboratory: Oak Ridge, TN, USA, 2011.

52. Bernstad, A.; la Cour Jansen, J. Review of comparative LCAs of food waste management systems-Current status and potential improvements. Waste Manag. 2012, 32, 2439-2455. [CrossRef] [PubMed]

53. Franchetti, M. Economic and environmental analysis of four different configurations of anaerobic digestion for food waste to energy conversion using LCA for: A food service provider case study. J. Environ. Manag. 2013, 123, 42-48. [CrossRef]

54. Khoo, H.H.; Lim, T.Z.; Tan, R.B.H. Food waste conversion options in Singapore: Environmental impacts based on an LCA perspective. Sci. Total Environ. 2010, 408, 1367-1373. [CrossRef]

55. Kim, M.-H.; Kim, J.-W. Comparison through a LCA evaluation analysis of food waste disposal options from the perspective of global warming and resource recovery. Sci. Total Environ. 2010, 408, 3998-4006. [CrossRef]

56. Levis, J.W.; Barlaz, M.A.; Themelis, N.J.; Ulloa, P. Assessment of the state of food waste treatment in the United States and Canada. Waste Manag. 2010, 30, 1486-1494. [CrossRef] [PubMed]

57. Yuan, S.X.; Tang, G.L.; Xiong, H.X.; Chen, J.; Yin, X.L.; Huang, G.Q. Area Estimation and Distribution Analysis of Subsurface Flow Constructed Wetlands at Regional Scale-Take Guangzhou City for Example. IOP Conf. Ser. Earth Environ. Sci. 2017, 51, 012025. [CrossRef]

58. Google. Google Maps' view of the location of Xiaoguwei Island and the region of Guangzhou n.d. Available online: https: / /www.google.com/maps (accessed on 12 November 2017).

59. Raposo, F.; De la Rubia, M.A.; Fernández-Cegrí, V.; Borja, R. Anaerobic digestion of solid organic substrates in batch mode: An overview relating to methane yields and experimental procedures. Renew. Sustain. Energy Rev. 2012, 16, 861-877. [CrossRef]

60. Ekstrand, E.-M.; Larsson, M.; Truong, X.-B.; Cardell, L.; Borgström, Y.; Björn, A.; Ejlertsson, J.; Svensson, B.H.; Nilsson, F.; Karlsson, A. Methane potentials of the Swedish pulp and paper industry-A screening of wastewater effluents. Appl. Energy 2013, 112, 507-517. [CrossRef]

61. Cunniff, P. (Ed.) Official Methods of Analysis of AOAC International; Association of Official Analitycal Chemists (AOAC): Washington, DC, USA, 2000.

62. APHA. Standard Methods for the Examination of Water and Wastewater; American Public Health Association: Washington, DC, USA, 1999.

63. Karlsson, A.; Ejlertsson, J.; Nezirevic, D.; Svensson, B.H. Degradation of phenol under meso-and thermophilic, anaerobic conditions. Anaerobe 1999, 5, 25-35. [CrossRef]

64. Feiz, R. Systems Analysis for Eco-Industrial Development: Applied on Cement and Biogas Production Systems. Ph.D. Thesis, Linköping University, Linköping, Sweden, 2016.

65. Hakawati, R.; Smyth, B.M.; McCullough, G.; De Rosa, F.; Rooney, D. What is the most energy efficient route for biogas utilization: Heat, electricity or transport? Appl. Energy 2017, 206, 1076-1087. [CrossRef]

66. US EPA Management Practices Chapters. Landfilling. In Documentation Chapters for Greenhouse Gas Emission and Energy Factors Used in the Waste Reduction Model (WARM); US EPA: Washington, DC, USA, 2016.

67. McAuliffe, G.A.; Chapman, D.V.; Sage, C.L. A thematic review of life cycle assessment (LCA) applied to pig production. Environ. Impact Assess. Rev. 2016, 56, 12-22. [CrossRef]

68. Mizesko, D. Climate Control Middle East. 2017. Available online: http:/ / climatecontrolme.com (accessed on 15 June 2017).

69. Ou, X.; Zhang, X.; Zhang, X.; Zhang, Q. Life cycle GHG of NG-based fuel and electric vehicle in China. Energies 2013, 6, 2644-2662. [CrossRef]

70. Li, X.; Ou, X.; Zhang, X.; Zhang, Q.; Zhang, X. Life-cycle fossil energy consumption and greenhouse gas emission intensity of dominant secondary energy pathways of China in 2010. Energy 2013, 50, 15-23. [CrossRef]

71. Xu, D.; Shen, D.; Feng, H.; Wang, M.; Deng, Y. Investigation and Countermeasures Analysis of Catering Waste in Southern City in China (In Chinese). Environ. Sci. 2011, 32, 2064-2168.

72. Li, Y.; Jin, Y.; Li, J.; Li, H.; Yu, Z. Effects of thermal pretreatment on the biomethane yield and hydrolysis rate of kitchen waste. Appl. Energy 2016, 172, 47-58. [CrossRef] 
73. Xiao, X.; Shi, W.; Huang, Z.; Ruan, W.; Miao, H.; Ren, H.; Zhao, M. Process stability and microbial response of anaerobic membrane bioreactor treating high-strength kitchen waste slurry under different organic loading rates. Int. Biodeterioration E Biodegr. 2017, 121, 35-43.

74. Wang, C.; Hong, F.; Lu, Y.; Li, X.; Liu, H. Improved biogas production and biodegradation of oilseed rape straw by using kitchen waste and duck droppings as co-substrates in two-phase anaerobic digestion. PLoS ONE 2017, 12, e0182361. [CrossRef] [PubMed]

75. Interview\#2; Our interview with Guangzhou Municipal Administration. July 2017.

76. Interview\#1; Our interview with Sub-District Office in Xiaoguwei Island. July 2017.

77. Interview\#6; Our interview with Institute of Energy Conversion. July 2017.

78. Interview\#4; Our interview with Guangzhou Datianshan Kitchen Waste Plant. July 2017.

79. Dong, J.; Ni, M.; Chi, Y.; Zou, D.; Fu, C. Life cycle and economic assessment of source-separated MSW collection with regard to greenhouse gas emissions: A case study in China. Environ. Sci. Pollut. Res. 2013, 20, 5512-5524. [CrossRef]

80. Woon, K.S.; Lo, I.M.C.; Chiu, S.L.H.; Yan, D.Y.S. Environmental assessment of food waste valorization in producing biogas for various types of energy use based on LCA approach. Waste Manag. 2016, 50, 290-299. [CrossRef]

81. Jin, Y.; Chen, T.; Chen, X.; Yu, Z. Life-cycle assessment of energy consumption and environmental impact of an integrated food waste-based biogas plant. Appl. Energy 2015, 151, 227-236. [CrossRef]

82. Chen, T.; Shen, D.; Jin, Y.; Li, H.; Yu, Z.; Feng, H.; Long, Y.; Yin, J. Comprehensive evaluation of environ-economic benefits of anaerobic digestion technology in an integrated food waste-based methane plant using a fuzzy mathematical model. Appl. Energy 2017, 208, 666-677. [CrossRef]

83. Liu, Y.; Sun, W.; Liu, J. Greenhouse gas emissions from different municipal solid waste management scenarios in China: Based on carbon and energy flow analysis. Waste Manag. 2017, 68, 653-661. [CrossRef] [PubMed]

84. Xu, C.; Shi, W.; Hong, J.; Zhang, F.; Chen, W. Life cycle assessment of food waste-based biogas generation. Renew. Sustain. Energy Rev. 2015, 49, 169-177. [CrossRef]

85. Čičková, H.; Newton, G.L.; Lacy, R.C.; Kozánek, M. The use of fly larvae for organic waste treatment. Waste Manag. 2015, 35, 68-80. [CrossRef] [PubMed]

86. Salomone, R.; Saija, G.; Mondello, G.; Giannetto, A.; Fasulo, S.; Savastano, D. Environmental impact of food waste bioconversion by insects: Application of Life Cycle Assessment to process using Hermetia illucens. J. Clean. Prod. 2017, 140, 890-905. [CrossRef]

87. Geels, F.; Raven, R. Non-linearity and Expectations in Niche-Development Trajectories: Ups and Downs in Dutch Biogas Development (1973-2003). Technol. Anal. Strateg. Manag. 2006, 18, 375-392. [CrossRef]

88. Fleck, J. Learning by trying: the implementation of configurational technology. Res. Policy 1994, 23, 637-652. [CrossRef]

89. Lantz, M.; Svensson, M.; Björnsson, L.; Börjesson, P. The prospects for an expansion of biogas systems in Sweden-Incentives, barriers and potentials. Energy Policy 2007, 35, 1830-1843. [CrossRef]

90. Raven, R.P.J.M.; Gregersen, K.H. Biogas plants in Denmark: Successes and setbacks. Renew. Sustain. Energy Rev. 2007, 11, 116-132. [CrossRef]

91. Fallde, M.; Eklund, M. Towards a sustainable socio-technical system of biogas for transport: The case of the city of Linköping in Sweden. J. Clean. Prod. 2015, 98, 17-28. [CrossRef]

(C) 2019 by the authors. Licensee MDPI, Basel, Switzerland. This article is an open access article distributed under the terms and conditions of the Creative Commons Attribution (CC BY) license (http://creativecommons.org/licenses/by/4.0/). 